\title{
Factors Affecting Student Interest Of Al-Quran Wonosobo Science University To Saving In A Syariah Bank
}

\author{
Mahgalena $^{1}$, Wahab ${ }^{2}$, Choirul Huda ${ }^{3}$ \\ 1,2,3Universitas Islam Negeri Walisongo Semarang, Indonesia. \\ mahgalenaa@gmail.com
}

\begin{abstract}
Purpose - This study aims to examine the effect of knowledge, location and religiosity on the interest of students at the University of Sains Al-Quran Wonosobo to save in Islamic bank.

Method - This research uses a type of field research with a quantitative approach. Sources of data in this study are primary data obtained from the results of a questionnaire by scoring using a likert scale. The population o this research is 100 students. In data analysis, the data analysis technique used is multiple linear regression analysis.

Result - The result showed that knowledge had a significant effect on interest in saving in Islamic bank, while location and religiosity did not significantly influence the interest in saving at Islamic banks. Then knowledge, location and religiosity simultaneously affect the interest in saving at Islamic banks.

Implication - This research can be used as input in getting customers with a high amount of savings in Islamic banks.

Originality - This study looked at the factors that influence the interest of students at the University of Sains Al-Quran Wonosobo to save in Islamic banks This research can be used as input in getting customers with a high amount of savings in Islamic banks.. In this study focused on 3 variables, namely variables of knowledge, location and religiosity.
\end{abstract}

Keywords: Knowledge; Location; Religiosity; Savings interest; Islamic bank. 
Mahgalena, Wahab, Choirul Huda

\section{Introduction}

Indonesia is a country with the largest Muslim population in the world, estimated at 229 million Muslims, where this number is $87.2 \%$ of the entire population of Indonesia, or around 13\% of the world's Muslim population.

AL-ARBAH | 48 Considered a late comer, Indonesia started the Islamic banking industry in 1992, almost a decade behind Malaysia with the establishment of Bank Muamalat Indonesia (BMI). Growth has not been too bad since then and in 2015 the Indonesian Islamic banking industry consisted of 12 Islamic commercial banks, 22 conventional Islamic bank business units and 161 Islamic people's credit banks with significant capital growth as well (Abdillah et al., 2020). Islamic banking is a sharia financial institution engaged in services using the principles of Islamic law. In its implementation, Islamic banks always apply the principle of prudence (Aufa et al., 2019). Sharia banking in Indonesia continues to develop, it has become a successful development of standards for its existence (Divine, et al., 2019).

There are several factors that can affect the interest in saving in Islamic banks, one of the factors that affect the interest in saving is knowledge. A person's knowledge of Islamic banks can influence people's interest in saving at Islamic banks. When people have more knowledge about Islamic banks, they will be more interested in becoming customers at Islamic banks. Apart from knowledge, another factor that can influence interest in saving is location. Strategic location, easy to reach by public transportation, close to crowd centers and safe is also another consideration for the community in choosing Islamic banking. Besides, The religiosity factor is also very high, the possibility of influencing people's interest in becoming a customer in a syariah bank because in Islam a person is required not only to think about something worldly but also the life of the brotherhood in doing muamalah deeds. In Islam, all activities carried out by a Muslim must be in accordance with Islamic law, including in economic activities (Suhirman, 2020). Economic practices taught in Islam are guidelines for Muslims that Islam is not only about prayer, but Islam teaches us how to carry out good and correct economic practices, all of which are taught in muamalah (Toyyibi, 2019). 
Based on research by Akhmad Darmawan, et al. (2019) stated that knowledge has a significant positive effect on customers' interest in saving at Islamic banks, in line with research by Ika Ramadhani, et al. (2019) states that knowledge has a positive and significant effect on student interest in saving at Islamic banks, different with the research results of Fajar Mujaddid, et al. (2019) stated that knowledge does not affect the interest in saving. In this study also used the location variable. The location in the research of Ida Lailatul Qodriyah (2016) states that location has a significant effect on the variable of interest in saving at the Muamalat bank, Madiun branch, which is not in line with the research of Akhmad Darmawan, et al. (2019) states that location has a negative and insignificant effect on the variable of interest in saving at a syariah bank. In addition to knowledge and location variables, this study also uses religiosity variables. Religiosity in the research of Nur'aini Ika Ramadhani, et al (2019) states that the level of religiosity has a positive and significant effect on students' interest in saving in Islamic banks. This is in line with the research of Raja Sakti Putra Harahap (2016) which states that simultaneously religion affects the intention of saving at the Muamalat bank and also in line with the research of Fajar Mujaddid, et al. (2019) states that religiosity has a significant effect on interest in saving, in contrast to Sayyidatul Maghfiroh's research (2018) ) which states that religiosity has no effect on interest in saving in Islamic banks. Religiosity in the research of Nur'aini Ika Ramadhani, et al (2019) states that the level of religiosity has a positive and significant effect on students' interest in saving in Islamic banks. This is in line with the research of Raja Sakti Putra Harahap (2016) which states that simultaneously religion affects the intention of saving at the Muamalat bank and also in line with the research of Fajar Mujaddid, et al. (2019) states that religiosity has a significant effect on interest in saving, in contrast to Sayyidatul Maghfiroh's research (2018) ) which states that religiosity has no effect on interest in saving in Islamic banks. Religiosity in the research of Nur'aini Ika Ramadhani, et al (2019) states that the level of religiosity has a positive and significant effect on students' interest in saving in Islamic banks. This is in line with the research of Raja Sakti Putra Harahap (2016) which states that simultaneously religion 
Mahgalena, Wahab, Choirul Huda

affects the intention of saving at the Muamalat bank and also in line with the research of Fajar Mujaddid, et al. (2019) states that religiosity has a significant effect on interest in saving, in contrast to Sayyidatul Maghfiroh's research (2018) ) which states that religiosity has no effect on interest in saving in Islamic banks.

Based on the problems that underlie this research because there were differences between the results of previous studies regarding interest in saving in Islamic banks, the authors wanted to know how the influence of knowledge, location and religiosity on interest in saving at Islamic banks in students of the Wonosobo Al-Quran Science University. While the purpose of this study was to test whether knowledge, location and religiosity affect the interest of students at the University of Science Al-Quran Wonosobo to save in Islamic banks.

\section{Literature Review}

\section{Interest in Saving}

Interest is an impulse that causes individual attention to certain objects such as work, lessons, objects and people. Interest is something that is learned, not innate and can change depending on needs, experiences and modes (Jahja, 2011). Saving according to Muhammad (2015) is an action recommended by Islam, because by saving means a Muslim prepares himself for the implementation of future planning as well as dealing with unwanted things. (Yuliani, et al., 2019). So the interest in saving is someone's desire to save money for future investment and for something that is sudden in the event of something unwanted.

Interest indicators according to Schiffman and Kanuk in Paragita (2013) are (1) Interested in finding information about products, (2) Want to know the product, (3) Interested in trying, (4) Considering buying, (5) Want to have a product (Aries et al., 2018).

Islamic Bank 
According to law no. 21 of 2008 Sharia Banks are banks that carry out their business activities based on sharia principles and by type consist of Sharia Commercial Banks (BUS) and Sharia Rural Banks (BPRS). As for what is meant by Sharia Bank according to Sri Susilo (2000) is a bank that in its activities both raising funds and in the framework of distribution and only provides and emphasizes rewards based on sharia principles, namely buying and selling and profit sharing (Rovita \& Yuwono, 2019). In law number 21 of 2008 concerning Islamic banking Article 4 explains the functions of Islamic banks, there are 4 functions of Islamic banks including (1) the function of the investment manager, (2) the function of the investor, (3) the function of banking services, (4) the social function(Wiroso, 2011).

\section{Knowledge}

According to Notoatmodjo (2014) knowledge is the result of someone knowing an object through their senses. Each person's knowledge will vary depending on how each person perceives an object or something (Masturoh, 2018). The understanding is almost the same according to bloom, namely knowledge is the result of knowing, and this happens after people do sensation of a certain object. According to another opinion from Pudjawidjana (1983) knowledge is the reaction of humans to stimuli by the surrounding environment through contact through objects with senses and knowledge is a result that occurs after people sense a certain object .(Wahyudi, et al., 2019). From this understanding, it can be concluded that knowledge is the view of humans in sensing or a stimulus that is formed through the five senses of a certain object.

Knowledge indicators, in dealing with product or service offerings, information that is owned by the community greatly influences people's behavior when purchasing products or services which divides knowledge into 4 types of product knowledge, namely (1) Knowledge of product characteristics or attributes, (2) Knowledge of benefits products, (3) Knowledge of product satisfaction, (4) Knowledge of the basic concepts of Islamic banks (Rosyid \& Saidah, 2016). 
Mahgalena, Wahab, Choirul Huda

\section{Location}

Location is a place where a type of business or business entity will be run. The choice of location has a strategic function because it can determine the achievement of the objectives of the business entity. Location is a fixed location or place where people can visit. From this understanding, it can be concluded that the location is a place that is the running of a business which can be easily visited by someone. Determining the right location can facilitate the running of a business because places that are easily accessible will attract interested people to come, especially locations at the bank.

Location indicators, there are several indicators in measuring location, among others; (1) Access with condition items, (2) Visibility with strategic items and clearly visible, (3) Traffic with density items and crowded locations, (4) Parking lots with wide and safe items (Hendrison, 2020).

\section{Religiosity}

According to Muzakir (2013) Religiosity is the attitude of diversity in a person or activities related to religion (Lestari et al., 2019). Religiosity is a concept that refers to social phenomena related to how religion lives within and is experienced by its adherents. Religiosity is the implementation of religion in religious human life (Warsiyah, 2018). Based on this definition, it can be concluded that religiosity is the implementation of religion in a person which includes thoughts, feelings and behavior as well as maintaining and increasing faith in accordance with the right path and purpose.

According to Glock and Strark in Ghufron and Risnawati where they argue that there are 5 dimensions of religiosity including: (1) Dimensions of belief, (2) Dimensions of worship or religious practice, (3) Dimensions of feeling or appreciation, (4) Dimensions of religious knowledge, (5) Dimensions of effect or experience (Hardiyanti et al., 2016).

\section{Hypothesis}


Based on the existing problems, the authors formulate the following hypothesis: The first hypothesis (H1): There is a significant influence of the knowledge variable on the interest of UNSIQ students to save in Islamic banks; Second hypothesis (H2): There is a significant effect of location variables on UNSIQ students' interest in saving in Islamic banks; The third hypothesis (H3): There is a significant influence of the religiosity variable on the interest of UNSIQ students to save in Islamic banks; The fourth hypothesis H4: Knowledge, location, and religiosity simultaneously have a significant effect on the interest of UNSIQ students to save in Islamic banks.

\section{Methods}

This type of research used in this research is field research with a quantitative approach. The data source in this research is primary data. The primary data used were obtained from the results of a questionnaire and given a score using a Likert scale that was distributed to predetermined respondents.

The population in this study were students of the Wonosobo Al-Quran Science University. By taking the sample using the Non Probability Sampling technique by means of purposive sampling, namely the technique of determining the sample with certain considerations or special selection. The reason researchers use this technique is because not all samples have the required criteria. The sample in this study were 100 people out of a total of 7,655 students who were obtained using the Slovin formula with a tolerance value of $10 \%$. Meanwhile, in data analysis, the data analysis technique used is multiple linear regression analysis.

\section{Results and Discussion}

\section{Characteristics of Respondents}

the number of respondents in this study were 100 respondents. Respondents consisted of 43 men or if presented it would be $43 \%$ and 57 women or if presented it would be $57 \%$. With this percentage, it can be seen that the gender is more dominant for women who do not have Islamic bank accounts for UNSIQ students. distributed. this study the respondents were 
Mahgalena, Wahab, Choirul Huda

divided into 3 parts. First, respondents from class 2017 were 33\%, which was the same number as respondents in class 2018. Second, respondents from class 2018 were 33\% and third, respondents from class 2019 were dominating, namely 34\% which was only 1\% difference from class 2017 and 2018. In this study were 100 from the 2017-2019 class which were divided into 7 faculties at UNSIQ. In this study, respondents based on the faculty were dominated by the first, the Faculty of Tarbiyah and Teacher Training (FITK), which was 34\%. Second, the Faculty of Engineering and Computer Science (FASTIKOM) as much as 27\%. Third, the Faculty of Economics (FE) as much as $21 \%$. Fourth, the Faculty of Sharia and Law (FSH) as much as $8 \%$. Fifth, the Faculty of Communication and Social Politics (FKSP) as much as 6\%. Sixth, the Faculty of Health Sciences (FIKES) as much as 3\%. Seventh, the Faculty of Language and Literature (FBS) as much as $1 \%$.

\section{Descriptive Analysis}

Based on the table 1, it can be identified that the distribution of respondent data on the knowledge variable (X1), location (X2), religiosity (X3) on the interest in saving ( $\mathrm{Y}$ ) in Islamic banks is good. Valid questionnaire items can be seen by the presence of a two star with a significant level of $5 \%$ on the pearson correlation value, besides that it can also be seen in the significance value if it is more than 0.05 then the question are item is valid. the knowledge variable (X1) and the location variable (X2) shows the value of the pearson correlation with the range $0.60-0.80$ which is included in medium and high validity, the variable Religiosity (X3) and interest in saving (Y) shows the value of the pearson correlation with range $0.40-0.70$ which falls under low, medium and high validity. So it can be concluded that the variables of knowledge (X1), location (X2), religiosity and interest in saving (Y) are declared valid.

The reliability test was measured by the Cronbach's Alpha statistical test where a variable was said to be reliable if the Cronbach Alpha value was more than 0.70 . The variables of knowledge (X1), location (X2), religiosity (X3) and interest in saving $(Y)$ were declared reliable because the Cronbach Alpha value was more than 0.70 . 
Factors Affecting Student Interest Of Al-Quran ...

Table 1. Descriptive Analysis

\begin{tabular}{ccccc}
\hline & $\mathbf{N}$ & \multicolumn{2}{c}{ Mean } & $\begin{array}{c}\text { Std. Deviation } \\
\text { Statistics }\end{array}$ \\
\hline Statistics & Statistics & Std. Error & .198 & 1,978 \\
Knowledge & 100 & 20.19 & .219 & 2,195 \\
Location & 100 & 19.97 & .335 & 3,354 \\
Religiosity & 100 & 58.61 & .203 & 2,026 \\
Interest in Saving & 100 & 26.42 & & \\
Valid N (listwise) & 100 & & & \\
\hline
\end{tabular}

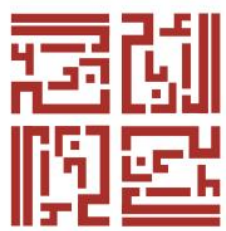

\section{Classic Assumption Test}

In table 2, the normality test was measured using a histogram, plot and Kolmogorov-Smirnov sample. On the histogram a variable is said to be normal if the line forms a mountain then on the plot of a variable it is said to be normal if the points in the image follow the diagonal lines, then in the KolmogorovSmirnov sample a variable is said to be normal if the significant value is more than 0.05. The results of the Kolmogorov Smirnov one sample test with a significance value of $0.200>0.05$, so it can be concluded that the data in the study were normally distributed.

Table 2. Komogorov Smirnov One Sample Test Results

\begin{tabular}{ccc}
\hline & & Unstandardized Residual \\
\hline Normal Parametersa, b & Mean & 100 \\
& Std. Deviation & .0000000 \\
Most Extreme Differences & Absolute & 1.88002424 \\
& Positive & .070 \\
& Negative & .062 \\
& & -.070 \\
Statistical Test & & .070 \\
Asymp. Sig. (2-tailed) & & $.200 \mathrm{c}, \mathrm{d}$ \\
\hline
\end{tabular}
a. Test distribution is Normal.
b. Calculated from data.
c. Lilliefors Significance Correction.
$\mathrm{d}$. This is a lower bound of the true significance. 
Mahgalena, Wahab, Choirul Huda

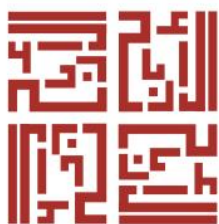

Table 4. Multiple Linear Regression Analysis

\begin{tabular}{|c|c|c|c|c|c|c|c|c|}
\hline & \multirow[b]{2}{*}{ Model } & \multicolumn{2}{|c|}{$\begin{array}{l}\text { Unstandardized } \\
\text { Coefficients }\end{array}$} & \multirow{2}{*}{$\begin{array}{c}\begin{array}{c}\text { Standardized } \\
\text { Coefficients }\end{array} \\
\text { Beta }\end{array}$} & \multirow[b]{2}{*}{$\mathbf{t}$} & \multirow[b]{2}{*}{ Sig. } & \multicolumn{2}{|c|}{ Collinearity Statistics } \\
\hline & & B & Std. Error & & & & Tolerance & VIF \\
\hline \multirow[t]{4}{*}{1} & (Constant) & 21,338 & 3,635 & & 5,870 & .000 & & \\
\hline & Knowledge & .382 & .102 & .373 & 3,745 & .000 & .905 & 1,105 \\
\hline & Location & .027 & .094 & .029 & .282 & .779 & .858 & 1,166 \\
\hline & Religiosity & -.054 & .060 & -.089 & -891 & .375 & .894 & 1,118 \\
\hline
\end{tabular}

a. Dependent Variable: Interest in Saving

The multicollenearity test results table 4 show that the VIF variable in the knowledge variable is $1.105<10$, the location variable is $1.166<10$, the religious variable is $1.118<10$ and the Tolerance Value value for the knowledge variable is $0.905>0.1$, the location variable is $0.858>0.1$ and the religiosity variable is $0.894>0.1$, So it can be concluded that the data in this study did not occur multicollinearity.

The results of the heteroscedasticity test can be seen that the significant value of the knowledge variable is $0.147>0.05$, the location variable is $0.964>$ 0.05 , the religiosity variable is $0.057>0.05$, so it can be concluded that in this heteroscedasticity test the significant value of the three variables is more than 0.05 so that heteroscedasticity does not occur. Heteroscedasticity will occur if the significant value of the variable is $<0.05$.

The results of multiple linear regression analysis with three independent variables obtain the following equation:

$$
\mathrm{Y}=21.338+0.382 \mathrm{X} 1+0.027 \mathrm{X} 2+0.054 \mathrm{X} 3
$$

From the equation, the following conclusions can be drawn: The constant value (a) is 21,338, where if knowledge, location and religiosity have zero values or no X1, X2, X3 values, then the student's interest in saving in Islamic banks has an increase of 21,338.

The coefficient value of the knowledge variable is positive at 0.382 , which means that if knowledge increases by $1 \%$ at the Al-Quran Science University, students' interest in saving in Islamic banks will increase by $0.382 \%$. 
The coefficient value of the location variable is positive at 0.027 , which means that if the location has increased by $1 \%$ at the Al-Quran Science University, the student's interest in saving in Islamic banks will increase by $0.027 \%$.

The coefficient value of the religiosity variable is negative -0.054 , which means that if the religiosity has increased by $1 \%$ at the Al-Quran Science University, the student's interest in saving in Islamic banks will decrease by $0.054 \%$.

The results of the t test (partial) table 4 can be explained by knowing in advance the $t$ table. By doing the calculations, the value of the table is 1.984 .

The results of the regression analysis of the knowledge variable (X1) on the interest in saving ( $\mathrm{Y}$ ) show that the $t$ value of 3,745 is greater than the table 1.984 and the sig $\mathrm{t}=0.000$ value is smaller than the value of $\alpha=5 \%$. This shows that the knowledge variable (X1) has a significant influence on the interest in saving in Islamic banks.

The results of the regression analysis of the location variable (X2) on the interest in saving (Y) show that the t value of 0.282 is smaller than the table 1.984 and the sig $\mathrm{t}=0.779$ is greater than the value of $\alpha=5 \%$. This shows that the location variable (X2) does not have a significant effect on the interest in saving in Islamic banks.

The results of the regression analysis of the religiosity variable (X3) on the interest in saving ( $Y$ ) show that the t value of -0.891 is smaller than the t table 1.984 and the sig $t=0.375$ value is greater than the value of $\alpha=5 \%$. This shows that the religiosity variable (X3) does not have a significant effect on the interest in saving in Islamic banks.

\section{The Influence of Knowledge on the Interest of UNSIQ Wonosobo Students in Saving in Islamic Banks}

Based on the research results, it can be seen that the knowledge variable has a significant effect on the interest in saving in Islamic banks, which means $\mathrm{H} 1$ is accepted and H0 is rejected. This can be seen in the test (partial) where 
Mahgalena, Wahab, Choirul Huda

t count is greater than $t$ table, namely $3,745>1,984$, besides that the sig $t$ value shows a smaller value than the $\alpha$ value, namely $0.000<0.05$, for that it can be concluded that the knowledge variable has a significant effect. towards the interest of UNSIQ Wonosobo students in supporting Islamic banks.

The results of this study are in accordance with the theory in chapter II where in the journal Sardita Hidayati and Multifiah, it is stated that knowledge has an influence on the interest in saving in Islamic banks because the higher the public's knowledge about Islamic banking and the more understanding of the existence of Islamic banks with an interest-free system, it will be the higher the public's interest in saving in Islamic banks.

\section{The Influence of Location on the Interest of UNSIQ Wonosobo Students in Saving in Islamic Banks}

Based on the research results, it can be seen that the location variable does not significantly influence the interest in saving in Islamic banks, which means $\mathrm{H} 1$ is rejected and $\mathrm{H} 0$ is accepted. This can be seen in the t test (partial) where t count is smaller than $t$ table, namely $0.282<1.984$, besides that the sig $t$ value shows a value greater than the $\alpha$ value, namely $0.779>0.05$, for that it can be concluded that the location variable is not has a significant effect on the interest of UNSIQ Wonosobo students to save in Islamic banks.

In this study it is not in line with Ida Lailatul Qodriyah, who in his research stated that the location variable partially has a significant negative effect on customer interest in saving at the Muamalat bank, Madiun branch. With the insignificance of the results of this study, which causes differences in the results of the study, at least it can be used as material for further review by future researchers.

\section{The Influence of Religiosity on UNSIQ Wonosobo Student Interest in Saving in Islamic Banks}

Based on the research results, it can be seen that the religiosity variable does not significantly influence the interest in saving in Islamic banks. which means $\mathrm{H} 1$ is rejected and $\mathrm{H} 0$ is accepted. This can be seen in the test (partial) 
where t count is smaller than $t$ table, which is $-0.891<1.984$, besides that the sig t value shows a value greater than the $\alpha$ value, namely $0.375>0.05$, for that it can be concluded that the variable of religiosity did not have a significant effect on the interest of UNSIQ Wonosobo students to save in Islamic banks.

In this study it is in line with Raja Sakti Putra Harahap who in his research stated that the religious variable did not have a significant effect on customer interest in saving on Mudharabah savings at the Muamalat bank branch of the Medan city hall. This shows that religiosity does not affect the interest in saving at a sharia bank because someone who understands religion and always implements the shari'a of his religion should have an interest in saving at a sharia bank to follow his religious teachings to avoid usury, but it turns out that there are still many students who are not interested in saving. in Islamic banks even though they already understand what their religion teaches.

\section{The Influence of Knowledge, Location, and Religiosity on the Interests of UNSIQ Wonosobo Students to Save in Islamic Banks}

Based on the research results, it can be seen that the variables of knowledge, location, and religiosity simultaneously affect the interest in saving in Islamic banks. This can be seen in the F test (simultaneous) where F count is greater than $\mathrm{F}$ table, namely 5,162> 2.70, besides that the sig $\mathrm{F}$ value shows a smaller value than the $\alpha$ value, namely $0.002<0.05$, for that it can be concluded that the knowledge variable, location, and religiosity simultaneously have a significant effect on the interest of UNSIQ Wonosobo students to save in Islamic banks.

\section{Conclusion}

Based on the results of the research and discussion that has been described about the factors that affect the interest of students of the Al-Quran Science University to save in Islamic banks using variables of knowledge, location, and religiosity, the following conclusions can be drawn:

The knowledge variable has a significant effect on the interest of students at the University of Sains Al-Quran Wonosobo to save in Islamic banks as seen 
Mahgalena, Wahab, Choirul Huda

from the $t$ test (partial) where $t>t$ table is $3,745>1,984$ with a significance value of $0.000<0.05$.

The location variable does not have a significant effect on the interest of students of the Al-Quran Science University to save in Islamic banks as seen from the $\mathrm{t}$ test (partial) where $\mathrm{t}$ count $<\mathrm{t}$ table is $0.282<1.984$ with a significance value of $0.779>0.05$.

The religiosity variable does not have a significant effect on the interest of students at the University of Sains Al-Quran Wonosobo to save in Islamic banks as seen from the t test (partial) where t count $<t$ table is $-0.891<1.984$ with a significance value of $0.375>0.05$.

The variables of knowledge, location, and religiosity simultaneously have a significant effect on the interest of students at the University of Sains AlQuran Wonosobo to save in Islamic banks as seen from the $F$ test (simultaneous) where $\mathrm{F}$ count $>\mathrm{F}$ table is $5,162>2.70$ with a significance value of $0.002<0.05$.

\section{References}

Abdillah, M. Y., Rabi, M. E., \& Firli, N. (2020). Tawarruq Apllication In Islamic Banking: A Comparative Study Between Malaysia And Indonesia. AL-ARBAH : Journal Of Islamic Finance And Banking, 2(1).

Aries, M., Sunarti, \& Mawardi, M. K. (2018). Pengaruh Word Of Mouth Terhadap Minat Beli Serta Dampaknya Pada Keputusan Pembelian (Survei Pada Make Up Artist yang Membeli dan Menggunakan Produk KRYOLAN di Kabupaten Bojonegoro). Jurnal Administrasi Bisnis, 60(2).

Aufa, K., Dja'kum, C. S., \& E. (2019). Risks Of Sharia Commercial Bank In Indonesia: Analysis Of Internal And External Factors. Al-ARBAH : Journal Of Islamic Finance and Banking, 1(1).

Hardiyanti, Tri, P., \& Nuryanta, N. (2016). Pengaruh Religiusitas 
Lingkungan Sekolah Terhadap Konsep Diri Siswa-Siswi Di MAN Pakem Sleman. Jurnal Nisbah, 13(1).

Hendrison, N. E. H. (2020). 2020. Jurnal Magisma, 8(1).

Jahja, Y. (2011). Psikologi Perkembangan. Prenadamedia Group.

Lestari, Shinta, S., \& Witri, T. M. (2019). Hubungan Antara Religiusitas

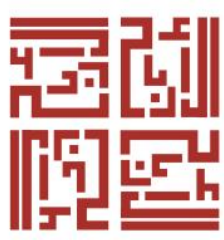

dan Kecerdasan Emosional Terhadap Komunikasi Sosial (Studi

Pada Perilaku Proposial Mahasiswa). Jurnal Medium, 7(1).

Masturoh, N. A. T. (2018). Metodologi Penelitian Kesehatan. Kementrian

Kesehatan Republik Indonesia.

Rosyid, M., \& Saidah, H. (2016). Pengetahuan Perbankan Syariah dan

Pengaruhnya Terhadap Minat Menabung Santri dan Guru. Jurnal

Islaminomic: Sekoah Tinggi Ekonomi Syariah (STES) Islamic Village, $7(2)$.

Rovita, A., \& Yuwono, T. (2019). Peran Bank Syariah Menuju Terciptanya

Ekonomi Kerakyatan (Studi Kasus Pada BNI Syariah Jakarta). Jurnal Ilmiah Manajemen Fokamma, 3(1).

Suhirman. (2020). ). The Future Of Sharia Based Village Business Agencies Religious Response Management Of Village-Owned Enterprises In Central Lombok. AL-ARBAH : Journal Of Islamic Finance And Banking, 2(1).

Toyyibi, A. M. (2019). Implementation Of Electronic Money In Developing Payment Transactions Through Islamic Economic Perspective. AL-ARBAH : Journal Of Islamic Finance And Banking, $1(1)$. 
Mahgalena, Wahab, Choirul Huda

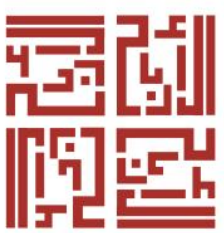

AL-ARBAH | 62 